\title{
"Environmental behavior practice in government agencies: Evidence from Kingdom of Saudi Arabia"
}

\begin{tabular}{|c|c|}
\hline AUTHORS & Abdulmalek Taher Alhajj (iD \\
\hline ARTICLE INFO & $\begin{array}{l}\text { Abdulmalek Taher Alhajj (2022). Environmental behavior practice in government } \\
\text { agencies: Evidence from Kingdom of Saudi Arabia. Problems and Perspectives } \\
\text { in Management, 20(1), 262-276. doi:10.21511/ppm.20(1).2022.22 }\end{array}$ \\
\hline DOI & http://dx.doi.org/10.21511/ppm.20(1).2022.22 \\
\hline RELEASED ON & Thursday, 17 February 2022 \\
\hline RECEIVED ON & Thursday, 02 December 2021 \\
\hline \multirow[t]{2}{*}{ ACCEPTED ON } & Tuesday, 08 February 2022 \\
\hline & $($ (c) EY \\
\hline LICENSE & $\begin{array}{l}\text { This work is licensed under a Creative Commons Attribution } 4.0 \text { International } \\
\text { License }\end{array}$ \\
\hline JOURNAL & "Problems and Perspectives in Management" \\
\hline ISSN PRINT & $1727-7051$ \\
\hline ISSN ONLINE & $1810-5467$ \\
\hline PUBLISHER & LLC "Consulting Publishing Company "Business Perspectives" \\
\hline FOUNDER & LLC "Consulting Publishing Company "Business Perspectives" \\
\hline
\end{tabular}

NUMBER OF REFERENCES

81

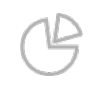

NUMBER OF FIGURES

1

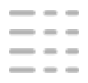

NUMBER OF TABLES

4

(C) The author(s) 2022. This publication is an open access article. 


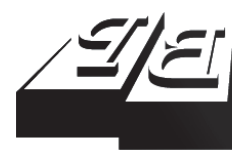

\section{BUSINESS PERSPECTIVES}

(O)

LLC "CPC "Business Perspectives" Hryhorii Skovoroda lane, 10, Sumy, 40022, Ukraine www.businessperspectives.org
Received on: $2^{\text {nd }}$ of December, 2021 Accepted on: $8^{\text {th }}$ of February, 2022 Published on: $17^{\text {th }}$ of February, 2022

(c) Abdulmalek Taher Alhajj, 2022

Abdulmalek Taher Alhajj, Ph.D., Assistant Professor, Department of Public Administration, College of Business Administration, King Saud University, Saudi Arabia.
This is an Open Access article distributed under the terms of the Creative Commons Attribution 4.0 International license, which permits unrestricted re-use, distribution, and reproduction in any medium, provided the original work is properly cited.

Conflict of interest statement: Author(s) reported no conflict of interest

Abdulmalek Taher Alhajj (Saudi Arabia)

\title{
ENVIRONMENTAL BEHAVIOR PRACTICE IN GOVERNMENT AGENCIES: EVIDENCE FROM KINGDOM OF SAUDI ARABIA
}

\begin{abstract}
Environmental behavior (EB) is a kind of organizational behavior that seeks to protect the natural environment and conserve resources, such as saving energy, recycling wastes, duplex printing, reducing water use, non-smoking in the workplace, and designing environmentally friendly products. This study aims to identify the degree of environmental behavior practice and examine its constraints in Saudi government agencies. This study is based on a single design of cross-sectional research. 436 responses were collected from employees of government agencies in Saudi Arabia. The study results indicated that the EB practice is generally high in government agencies.

Furthermore, the results revealed that female employees in government agencies have no statistical difference from male employees. In other words, the EB practice of men and women in government agencies is equal. The study also found a significant difference between married, unmarried, and divorced groups. Divorced employees report a higher level of EB than other employee groups. However, the study indicated a significant difference between the high school, graduate, and postgraduate groups. In other words, employees with high school education have a higher level of EB. Receiving and not receiving leadership support have a significant difference, whereas employees who received environmental training reported higher levels of EB than others. The outcomes also indicated a difference between the group of employees who have religious values. The outcomes of this study may be of benefit to researchers, regulators, policymakers, managers, and governors.
\end{abstract}

\section{Keywords}

JEL Classification

\section{INTRODUCTION}

Environmental sustainability has become a vital issue for societies in the $21^{\text {st }}$ century. Consequently, governments and international organizations in various fields began translating this concept into concrete actions through environmental policies, programs, and initiatives. For example, public and private organizations have encouraged employees to adopt environmental concepts and behavior (EB) to conserve the natural environment and resources from pollution due to waste. Moreover, many organizations have integrated new scientific concepts, such as green organizations, policies, and human resource management (HRM), into their processes, practices, and functions. They aim to enhance environmental sustainability and create an excellent image for members of society (Cherian \& Jolly, 2012; Mashala, 2018; Pham et al., 2019). As a global approach, the concept of green HRM refers to building and developing the workforce to enable understanding and embodiment of environmental standards in their behaviors (Ahmad \& Nisar, 2015). 
However, this concept is rarely studied in the Arab world, particularly in Saudi Arabia, despite the continuous increase in studies of green behavior in the west (Albahairy, 2018; Ibrahim, 2018).

Notably, Saudi Arabia is one of the 20 countries globally whose economy depends mainly on oil and has a powerful administrative system comprising 1,244,811 government employees as of 2019 (General Authority for Statistics, 2019). In 2015, Saudi Arabia adopted a strategic plan known as Vision 2030, which emphasized the efficiency of administrative and financial spending, reducing the waste in money, water, and natural resources, and enhancing environmental sustainability. Therefore, this study attempts to bridge the gap in this area. It presents an accurate picture of EB practice of employees and its determinants, which drives leaders and decision-makers to take measures and incentives to encourage employees to support sustainability in a high manner. Remarkably, studies on EB in public organizations remain few because previous studies focused on private organizations.

\section{LITERATURE REVIEW AND HYPOTHESES DEVELOPMENT}

Organizations have focused on maximizing efficiency and profits only in the past decades, without any interest in environmental sustainability (Masri \& Jaaron, 2017). However, environmental protection has become a global issue since the 1990s (Anderson et al., 2015; Haney et al., 2020; Iqbal et al., 2018; Kim et al., 2019; Pham et al., 2019). Therefore, these organizations attempted to raise awareness of their employees' green practices and environmental management techniques to decrease their pollution contributions (Ahmad \& Nisar, 2015; Tuân et al., 2014). Moreover, public organizations have considered the environmental concern and incorporated the environmental dimension into their plans, operations, and services (Mashala, 2018). Hence, employees in organizations can help reduce environmental pollution and resource wastage through voluntary environmental activities.

This study is based on the theory of planned behavior (TPB), a psychological theory developed by Ajzen (1985). It assumes that an individual's behavior depends on his intention to perform any action (Figure 1). This assumption implies that the central factor in this theory is behavioral intention, which can be predicted through the following three main components: attitudes, subjective norms, and perceived behavioral control (Beck \& Ajzen, 1991). Attitudes refer to the degree to which a person has a favorable or unfavorable evaluation of the behavior of interest. Subjective norms refer to the belief of whether most people (e.g., friends, family, spouse, coworkers, or supervisors) approve or disapprove of performing the behavior. Finally, perceived behavioral control refers to a person's perception of the ease or difficulty of performing the behavior of interest (Ajzen, 2015; Gatfield \& Chen, 2006).

TPB states that individuals who have strong positive intentions toward the environment actively participate in environmentally-friendly activities (Fielding et al., 2008; Octav-Ionut, 2015; Yuriev et al., 2020). Many studies have been conducted in different contexts according to this theory.

For example, Octav-Ionut (2015) used this theory in Romania to predict the environmental behavior of energy consumers and their conservation and action intentions in an environmentally friendly manner. TPB was also used in California and Luxembourg to predict the behavioral intention of residents to conserve water (Liang et al., 2018) and understand the beliefs that influence the pro-environmental behavior of high school students (Leeuw et al., 2015), respectively. This theory was employed in Australia and Malaysia to verify the intentions of university students to engage in environmental activities (Fielding et al., 2008; Mat et al., 2020).

Moreover, this theory was utilized to predict the recycling behaviors among college students in Hong Kong (Cheung et al., 1999) and pre-service teachers in Turkey (Pamuk \& Kahriman-Pamuk, 2019), the recycling behaviors in Canada (Lakhan, 2018), and South Africa (Strydom, 2018). By contrast, TPB was used to predict the green buying 


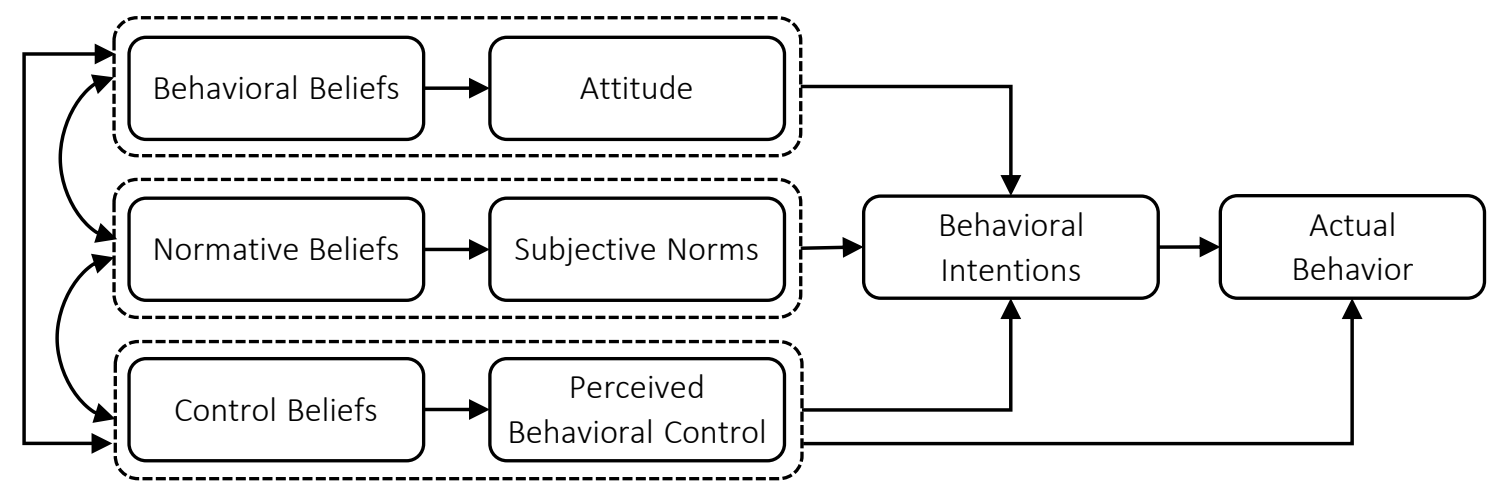

Figure 1. Theory of planned behavior model

behavior and the intention to purchase green products among the population in India (Yadav \& Pathak, 2017), Indonesia (Setyawan et al., 2018), China (Zhang et al., 2019), and Singapore (Ho et al., 2015).

\subsection{Definitions of environmental behavior (EB)}

The literature defines EB in the workplace in several terms: green behavior, pro-EB, and ecological behavior (Liu et al., 2018). In addition, the concept of "green employee" is used to describe an employee who has an identity and a fundamental drive to protect the environment through his/her job (Amenumey, 2015). Thus, a set of these definitions is provided as follows.

EB is a measurable action and activity of employees that contribute to environmental sustainability (Ones \& Dilchert, 2012). Stern (2000) defined $\mathrm{EB}$ as an intended behavior that seeks to reduce the negative impact on the natural environment. Moreover, Kollmuss and Agyeman (2002) held that $\mathrm{EB}$ is the conscious aim to minimize the negative impact of an individual's actions on the natural environment. Similarly, Ramus and Steger (2000) indicated that EB constitutes the initiatives and actions of employees who believe that these actions will improve the company's environmental performance. Moreover, employee characteristics, such as environmental activeness, address major environmental issues, provide suggestions for improving organizational practices, and help investigate environmentally harmful practices of companies and governments (Aziz et al., 2018; Warrick, 2016).

\subsection{Types and benefits of environmental behavior}

EB in organizations may take several patterns. For example, it may be saving energy, recycling wastes, duplex printing, using environmentally friendly transportation, purchasing recyclable goods, reducing water use, removing sources of pollutant emissions, and designing environmentally friendly products (Janmaimool \& Denpaiboon, 2016; Unnikrishnan \& Hegde, 2007; Warrick, 2016). EB also contains various ideas, such as searching for superior environmental activities, suggesting reducing damaging effects, creating green processes and products, volunteering in environmental tasks, participating in activities beyond the job description, and encouraging others to solve environmental problems (Graves et al., 2013).

Furthermore, EB may comprise cooperation in promoting environmental initiatives, adhering to pro-environmental policies, complying with environmental values, applying environmental standards and regulations, exchanging knowledge, gaining skills to understand issues, and participating in sustainable development programs (Boiral, 2009).

Various classifications of environmental-related organizational behaviors have been developed. For example, Ones and Dilchert (2012) provided the following taxonomy: working sustainably, avoiding damage, conserving resources, influencing others, taking on initiatives. In addition, Norton et al. (2015) indicated that the green behavior of employees is categorized into formal and voluntary green behaviors, which are respectively motivated by official authority and self-motivation. 


\subsection{Environmental behavior dimensions}

Several studies examined the relationship between gender and EB in organizations in different environments, such as Hines et al. (1987), who concluded that gender and EB in organizations have a weak positive relationship. Additionally, Zelezny et al. (2000) found that women generally record stronger attitudes and actions toward the environment than men. Chen et al. (2011) also indicated that a random sample from the University of China revealed that females are more likely to participate in EB than males. On the contrary, Patel et al. (2017) found that males exercise higher EB than females. In contrast, Liu et al. (2018) found that the EB participation of women and men in Chinese organizations is generally equal. Finally, in Spain, Vicente-Molina et al. (2018) conducted a study on a sample of 1,089 university students and revealed that gender is one of the most critical determinants of EB.

Marital status may represent one of the environmental factors of organizations. For example, Chen et al. (2011) stated that single respondents showed higher participation in environmental activities than married respondents at the University of China. By contrast, Hlaing (2016) concluded that single employees are less involved in environmental conservation than married employees. Additionally, Patel et al. (2017) indicated that married consumers practice more pro-environment behaviors than single consumers.

Many studies used education variables, such as Hines et al. (1987), who showed that education and EB have a relatively high positive relationship. Similarly, Patel et al. (2017) found that highly educated consumers exhibit environmentally friendly behaviors more than consumers with low qualifications. Furthermore, Amenumey (2015) revealed a significant positive relationship between educational level and EB practice in textile factories in Ghana. On the contrary, Hlaing (2016) revealed that employees with low educational levels are more involved in EB practice than those with high educational levels.

The values and behaviors of leaders are crucial in shaping the ethical behavior of their followers (Haney et al., 2020; Russell, 2001). Ramus and
Killmer (2007) revealed four factors that drive the EB of workers, including support from a direct supervisor. Tuân et al. (2014) conducted a study on a sample of employees from three Vietnamese companies. They found that leadership and supervisory support affect the willingness of employees to practice and promote environmental initiatives. Moreover, Blok et al. (2015) indicated that leadership is one of the institutional factors that stimulate the EB of employees based on a sample of staff from Wageningen University.

Similarly, Raineri and Paillé (2016), on a sample of several organizations in France, found that leadership support impacts the involvement of employees in environmental citizenship behaviors. Moreover, Papagiannakis and Lioukas (2018) studied industrial companies in Greece and indicated a significant relationship between charismatic characteristics and the adoption of voluntary environmental practices of managers.

Training is vital for various organizations (Haney et al., 2020). This type of training is defined as the systematic process for improving employee knowledge, skills, and attitudes toward achieving the environmental goals of the organization (Pinzone et al., 2019, p. 222). In addition, it helps effectively create an environmentally friendly organization (Renwick et al., 2013). Environmental training assists an organization in protecting the environment through the following three aspects: promoting awareness, developing knowledge, and building a climate (Ren et al., 2018).

Certain studies examined the relationship between environmental training and EB in organizations. For instance, a study conducted in India on a sample of 16 industrial organizations found that more than half of the organizations prioritized different types of training in environmental management, which positively influenced clean production (Unnikrishnan \& Hegde, 2007). Moreover, Pham et al. (2019) conducted a study on luxury hotels in Vietnam and found that green training fundamentally impacts the environmental commitment of employees. In addition, Pinzone et al. (2019) investigated Italian hospital specialists and showed that green training is related to the EB practice of employees and motivates them to serve the environment. Cabral and Dhar (2019) showed that green 
training directly positively impacts the green competencies of workers in India. Furthermore, Singh et al. (2019) studied a sample of 16 organizations in the United Arab Emirates. They indicated that the environmental training of employees positively affects the environmental performance and competitive advantage of the company.

Religious values are one of the components of a society's system of values. Religious values shape human behavior toward all creatures, such as plants and animals (Abedi-Sarvestani \& Shahvali, 2008). All religions emphasize the importance of protecting natural resources, and the Islamic religion also gives importance to preserving the environment and using available resources (Akhtar, 1996; Razzaq et al., 2018).

Thus, Helfaya et al. (2018) stated that the Holy Qur'an, which is the main book in Islam, includes 675 verses that advocate natural environment protection and all its elements (humans, water, air, earth, plants, animals, and other natural resources). In this context, through the study on the role of Islam values in EB in Egypt, Rice (2006) concluded that religious teachings and religiosity are related to behaviors that protect the environment and motivate individuals to promote behaviors.

Subsequently, Ali et al. (2015) conducted a study on a sample of students from the International Islamic University in Pakistan (IIUI). They indicated that those aware of their religious teachings on environmental protection have a strong willingness to participate in activities that support such teachings. Furthermore, in Saudi Arabia, Islamic values influence the administrative practices of organizations (Ibrahim, 2018). Consequently, religious values may influence the $\mathrm{EB}$ of employees in government agencies.

Accordingly, this study aims to examine the degree of environmental behavior (EB) practice in government agencies in Saudi Arabia. The following hypotheses were formulated based on the arguments shown in the literature review as well as the study purpose:

H1: Female employees in government agencies are more likely to report higher levels of $E B$ than male employees.
H2: $\quad$ Married employees in government agencies are more likely to report higher levels of $E B$ than other employee groups.

H3: Employees in government agencies with high educational levels are more likely to report higher levels of EB than other employee groups.

H4: Employees in government agencies who receive leadership support are more likely to report higher levels of EB than those who do not receive such support.

H5: Employees in government agencies who receive environmental training are more likely to report higher levels of EB than those who do not receive such training.

H6: Employees in government agencies with religious values are more likely to report higher levels of EB than other employee groups.

\section{METHODS}

The population of this study consisted of workers in the ministries of a civil nature in the Saudi government, which numbered 24 ministries. Five ministries were intentionally selected, including Ministry of Education, Ministry of Health, Ministry of Human Resources and Social Development, Ministry of Trade and Industry, and Ministry of Finance. They are one of the largest and vital ministries in which many employees work and have shown their cooperation in distributing the study tool to the study community. A total of 600 questionnaires, which have an approximately $73 \%$ response rate because 436 were returned, were distributed.

The scale of EB in the workplace developed by Paillé and Boiral (2013) was used for data collection. The scale included 3 dimensions and 10 items; Eco-Initiative was measured using (3) items, Ecocivic Engagement was measured through (4) items, and Eco-helping was measured using (3) items (Table A1). Moreover, the scale was based on a five-point Likert scale (strongly agree $=5$, strongly disagree $=1$ ). Furthermore, the questionnaire of this study included the following six factors: gen- 
der (male $=1$, female $=2)$, marital status (married $=1$, unmarried $=2$, divorced $=3$ ), educational level (high school $=1$, graduate $=2$, postgraduate $=$ 3 ), leadership support (receives support $=1$, does not receive support $=2$ ), environmental training (yes $=1$, no $=2$ ), and the role of Islamic values on the EB of employees (effective $=1$, not effective $=$ 2 , null = 3) (Appendix A). Notably, the questionnaire was translated from English into Arabic, and professionals reviewed the translation quality before distribution to the study sample. The convenient sample was chosen of government agency employees. Then, the questionnaire was distributed to a sample of 30 participants for pilot testing to verify the accuracy of the translation and the understanding of participants of questionnaire items. The Pearson correlation coefficient was then calculated and showed that each item is positively correlated with the overall degree of dimension and statistically significant (0.01). Moreover, the reliability of the questionnaire was tested using Cronbach's alpha. The general reliability was (0.88), which indicates the validity of the questionnaire for field application.

\section{RESULTS}

\subsection{Descriptive analysis}

Table 1 shows that the sample comprises males (68.1\%) and females (31.8\%), reflecting the nature of the workforce composition in government agencies. Women's work in specific jobs and activities has some restrictions. Considering marital status, the majority is married (79.8\%), and the rest is single (16.2\%). This result is expected in a conservative society, such as Saudi society, where Islam affects many aspects of life. The results also show that most hold a university qualification (57.79\%), followed by postgraduates (32.33\%). However, the percentage of those with high school education was only $9.86 \%$ because the government stopped last year's appointment from this category.

Table 1 also reveals that most participants (53.44\%) received support from their superiors toward environmental protection in government agencies. In contrast, a relatively large percentage (46.55\%) did not receive any support from their superiors in this area. Moreover, the vast majority of the participants $(91.05 \%)$ did not receive any training program in environmental management. This result confirms that awareness of the environment and its sustainability remains weak in Saudi government agencies. Regarding religious values, most of the respondents (84.17\%) believe that Islamic values are effective in the $\mathrm{EB}$ of employees in the workplace.

Table 1. Description of study participants

\begin{tabular}{|c|c|c|c|}
\hline Variable & Category & Frequency & Percentage \\
\hline \multirow{2}{*}{ Gender } & Male & 297 & 68.1 \\
\hline & Female & 139 & 31.9 \\
\hline \multirow{3}{*}{ Marital status } & Married & 348 & 79.8 \\
\hline & Unmarried & 71 & 16.3 \\
\hline & Divorced & 17 & 3.9 \\
\hline \multirow{3}{*}{$\begin{array}{l}\text { Educational } \\
\text { level }\end{array}$} & High school & 43 & 9.9 \\
\hline & Graduate & 252 & 57.8 \\
\hline & Postgraduate & 141 & 32.3 \\
\hline \multirow{2}{*}{$\begin{array}{l}\text { Leadership } \\
\text { support }\end{array}$} & Receives support & 233 & 53.4 \\
\hline & $\begin{array}{l}\text { Does not receive } \\
\text { support }\end{array}$ & 203 & 46.6 \\
\hline \multirow{2}{*}{ Training } & Yes & 39 & 8.9 \\
\hline & No & 397 & 91.1 \\
\hline \multirow{3}{*}{$\begin{array}{l}\text { Religious } \\
\text { values }\end{array}$} & Effective & 367 & 84.2 \\
\hline & Not effective & 22 & 5.0 \\
\hline & Null & 47 & 10.8 \\
\hline
\end{tabular}

\subsection{Level of EB practice in the government agencies}

Table 2 shows that EB has an average of 3.52 and a standard deviation (SD) of 1.11. This result indicates that the degree of $\mathrm{EB}$ practice is high in government agencies in general. However, Table 2 shows that the Eco-Initiative dimension obtained a high average of 3.71 and SD of 1.09. This result can be explained under the theory of planned behavior (TPB). The study sample may have positive attitudes toward the environment, which constitute the behavioral intention, subsequently driving them to present good initiatives to protect the environment in the workplaces. This finding is confirmed by Bissing-Olson et al. (2013) on some Australian organizations, who indicated that employees' environmental attitudes help organizations develop EB in the workplace. Wesselink et al. (2017) also found a strong relationship between environmental attitudes and behavior through their study on employees in the public sector in the Netherlands. 
According to the study scale, the Eco-Civic Engagement dimension obtained an average of 3.22 and SD of 1.16, which means neutral choice. In the Perceived Behavioral Control dimension, the TPB assumes that the individual may have positive attitudes toward something and a behavioral intention but cannot participate due to internal and external constraints that prevent the individual from doing anything (Beck \& Ajzen, 1991). These constraints include direct and indirect situational and institutional barriers (Harland et al., 2007; Jurin \& Fortner, 2002; Kollmuss \& Agyeman, 2002; Wesselink et al., 2017). So that, the sample in the current study may possess the behavioral intention but cannot actively participate in environmental events and activities due to the following potential obstacles: lack of environmental activities adopted by the organization, the absence of green leaders, limited environmental tasks in the description, the absence of green organizational culture, the lack of green rewards, the ineffectiveness of the information and communication system, and the weakness of facilities, such as green buildings and recycling tools. Abdulghaffar (2017) concluded that leadership is one of the obstacles to practicing green behavior by employees based on her study within the Saudi context.

Table 2 shows that the Eco-helping dimension attained an average of 3.64 and SD of 1.08. Considering TPB, the Subjective Norms dimension assumes that an individual behaves when other people (colleagues and supervisors) approve of performing the behavior. Therefore, the study sample may assist colleagues in the workplace, whether in actions, encouragement, or advice, to make practical contributions to environmental sustainability.

\subsection{Empirical analysis}

This sub-section presents the outcomes of the current study. This study employed the MannWhitney and the Kruskal-Welles tests to test the hypotheses. The results are presented as follows.

\subsubsection{Hypothesis 1}

Female employees in government agencies are more likely to report a higher level of EB than male employees. However, Table 3 shows no statistical difference between these two groups ( $p>0.05)$, thereby rejecting $H 1$. In other words, the EB practice of men and women in government agencies is equal. This finding can be explained by the fact that preserving the environment and its resources is a concern and responsibility of both male and female employees. Such a goal is related to the interests of their own, their organization, and their country.

\subsubsection{Hypothesis 2}

Married employees in government agencies are more likely to report a higher level of EB than

Table 2. Means (M) and standard deviation (SD) of environmental behavior

\begin{tabular}{|c|c|c|c|}
\hline Dimensions & Items & Mean & SD \\
\hline \multirow{4}{*}{ Eco-initiatives } & $\begin{array}{l}\text { In my work, I weigh the consequences of my actions before doing something that could affect } \\
\text { the environment }\end{array}$ & 3.85 & 1.04 \\
\hline & I voluntarily carry out environmental actions and initiatives in my daily work activities & 3.74 & 1.08 \\
\hline & $\begin{array}{l}\text { I make suggestions to my colleagues about ways to protect the environment effectively even } \\
\text { when it is not my direct responsibility }\end{array}$ & 3.54 & 1.16 \\
\hline & Mean & 3.71 & 1.09 \\
\hline \multirow{5}{*}{$\begin{array}{l}\text { Eco-civic } \\
\text { engagement }\end{array}$} & I actively participate in environmental events organized in and/or by my company & 3.16 & 1.18 \\
\hline & I stay informed about my company's environmental initiatives & 3.16 & 1.16 \\
\hline & I undertake environmental actions that contribute positively to the image of my organization & 3.43 & 1.16 \\
\hline & $\begin{array}{l}\text { volunteer for projects, endeavors, or events that address environmental issues in my } \\
\text { organization }\end{array}$ & 3.12 & 1.16 \\
\hline & Mean & 3.22 & 1.16 \\
\hline \multirow{4}{*}{ Eco-helping } & $\begin{array}{l}\text { I spontaneously give my time to help my colleagues take the environment into account in } \\
\text { everything they do at work }\end{array}$ & 3.55 & 1.1 \\
\hline & I encourage my colleagues to adopt more environmentally conscious behaviors & 3.73 & 1.04 \\
\hline & I encourage my colleagues to express their ideas and opinions on environmental issues & 3.65 & 1.11 \\
\hline & Mean & 3.64 & 1.08 \\
\hline \multicolumn{2}{|l|}{ Overall mean } & 3.52 & 1.11 \\
\hline
\end{tabular}


other employee groups. Table 3 shows the significant differences between married, unmarried, and divorced groups $(\mathrm{p}<.05)$. The mean rank (255.79) indicates a difference in the divorced group, thereby rejecting $\mathrm{H} 2$. Divorced employees report a higher level of EB than other employee groups. This finding may be ascribed to the fact that divorced employees have fewer family responsibilities compared with married ones, thereby giving them some time to engage in environmental activities at the workplace. Meanwhile, divorced employees report a higher level of EB than single employees, probably due to their marriage failure, which has made them more mature and responsible for life and the environment.

\subsubsection{Hypothesis 3}

Employees in government agencies with high educational levels are more likely to report higher levels of EB than other employee groups. Table 3 shows significant differences between the high school, graduate, and postgraduate groups $(\mathrm{p}<$ $.05)$. Mean rank $=271.58$, indicating that the difference is for employees with high school education. In other words, employees with high school education have a higher level of EB than others, thereby rejecting $H 3$. This result may be attributed to the job responsibilities of these employees, which primarily focus on simple tasks, such as guarding, cleaning, and reception, which does not require the use of materials or engagement in activities that harm the environment. Moreover, these employees do not occupy critical positions in the government, thereby affording them some time to volunteer in environment-related activities. By contrast, graduate and postgraduate employees are usually placed in significant administrative and leadership positions that drain all their time and effort, distracting them from environmental sustainability.

\subsubsection{Hypothesis 4}

Employees in government agencies who receive leadership support are more likely to report higher levels of EB than those who do not receive such support. Table 3 also shows that the two groups, namely those who receive and do not receive leadership support, significantly differ $(\mathrm{p}<0.05$; mean rank $=262.63)$. Therefore, this result supports $H 4$. This result seems logical because administrative leaders act as role models for employees (Ibrahim, 2018). In addition, leaders who have a vision and mission directed toward the environment always motivate their employees to engage in environmental initiatives and rationalize their organization's resources. Therefore, employees directly and indirectly affected by their leaders provide essential contributions to environmental management.

\subsubsection{Hypothesis 5}

Employees in government agencies who receive environmental training are more likely to report higher levels of EB than those who do not receive such training. Table 3 shows that the two groups significantly differ $(\mathrm{p}<.05)$. The mean rank $=$ 304.96 indicates that the difference is for the group that received training. This means that employees who received environmental training reported higher levels of EB than others, thereby supporting H5. Training is among the most critical tools for organizational change (Singh et al., 2019). Environmental training is essential for employees and leaders to promote green culture, build their skills, shape their attitudes, and transform themselves into environment-friendly human beings capital.

\subsubsection{Hypothesis 6}

Employees who have religious values are more likely to report higher levels of EB in government agencies than other groups. Table 3 shows a significant difference between the three groups ( $\mathrm{p}<$ .05). The mean rank $=225.77$ indicates that the difference is for employees who have religious values. Therefore, $\mathrm{H} 6$ is supported. As the official religion of Saudi Arabia, Islam calls for the protection of the natural environment and its components (Helfaya et al., 2018). For example, Muslims are forbidden to waste water and food, cut down trees, or smoke. While all citizens of Saudi Arabia are exposed to these religious values and teachings, they differ in how they apply these teachings in life. Some may embrace and apply these values in social and institutional situations, whereas others may show less commitment to them or do not see their importance. 
Table 3. Mann-Whitney and Kruskal-Wallis tests

\begin{tabular}{|c|c|c|c|c|}
\hline \multicolumn{5}{|c|}{$\begin{array}{c}\text { Mann-Whitney U test for difference between two } \\
\text { groups toward EB }\end{array}$} \\
\hline Gender & $\mathbf{N}$ & Mean rank & Sum of ranks & $\mathbf{P}$ \\
\hline Male & 297 & 217.8 & 64686.5 & \multirow{2}{*}{0.86} \\
\hline Female & 139 & 220 & 30579.5 & \\
\hline $\begin{array}{l}\text { Leadership } \\
\text { support }\end{array}$ & $\mathbf{N}$ & Mean rank & Sum of ranks & $\mathbf{P}$ \\
\hline Receive support & 233 & 262.63 & 61193.5 & \multirow[b]{2}{*}{0.0} \\
\hline $\begin{array}{l}\text { Does not receive } \\
\text { support }\end{array}$ & 203 & 167.84 & 34072.5 & \\
\hline $\begin{array}{c}\text { Environmental } \\
\text { training }\end{array}$ & $\mathbf{N}$ & Mean rank & Sum of ranks & $\mathbf{P}$ \\
\hline Yes & 39 & 304.96 & 11893.5 & \multirow{2}{*}{0.0} \\
\hline No & 397 & 210.01 & 83372.5 & \\
\hline \multicolumn{5}{|c|}{$\begin{array}{l}\text { Kruskal-Wallis test for the difference between three } \\
\text { groups toward EB }\end{array}$} \\
\hline Marital status & $\mathbf{N}$ & Mean rank & Chi-square & $\mathbf{P}$ \\
\hline Married & 348 & 222.76 & \multirow{3}{*}{6.42} & \multirow{3}{*}{0.04} \\
\hline Unmarried & 71 & 188.68 & & \\
\hline Divorced & 17 & 255.79 & & \\
\hline $\begin{array}{c}\text { Educational } \\
\text { level }\end{array}$ & $\mathbf{N}$ & Mean rank & Chi-square & $\mathbf{P}$ \\
\hline High school & 43 & 271.58 & \multirow{3}{*}{11.35} & \multirow{3}{*}{0.01} \\
\hline Graduate & 252 & 219.24 & & \\
\hline Postgraduate & 141 & 200.99 & & \\
\hline $\begin{array}{l}\text { Religious } \\
\text { values }\end{array}$ & $\mathbf{N}$ & Mean rank & Chi-square & $\mathbf{P}$ \\
\hline Effective & 367 & 225.77 & \multirow{3}{*}{10.87} & \multirow{3}{*}{0.01} \\
\hline Not effective & 22 & 225.73 & & \\
\hline Null & 47 & 163.82 & & \\
\hline
\end{tabular}

\section{DISCUSSION}

It has been found that female employees in government agencies have no statistical difference from male employees in Saudi government agencies. In other words, the EB practice of men and women in government agencies is equal. This result is consistent with Liu et al. (2018), who revealed that the participation of women and men in EB practice in Chinese organizations is equal. However, this result differs from Chen et al. (2011), Digby (2013), Patel et al. (2017), and Vicente-Molina et al. (2018), who found the relationship between gender and EB in organizations.

The results showed a significant difference between married, unmarried, and divorced groups. Divorced employees report a higher level of EB than other employee groups. This finding contradicts Chen et al.
(2011), who stated that single employees have higher participation in EB than married employees. By contrast, Hlaing (2016) confirmed that single employees are less involved in environmental protection than married employees. The outcome revealed a significant difference between the high school, graduate, and postgraduate groups. Employees with high school education have a higher level of EB than others. This finding is consistent with Digby (2013) and Hlaing (2016). They showed that employees with low levels of education are more involved in environmental protection than those with a high level of education. However, this result differs from Patel et al. (2017), who found that highly qualified individuals show EB more than those with low qualifications.

The findings indicated that leadership support has a significant difference $(\mathrm{p}<.05)$. This outcome is consistent with Digby (2013), Ibrahim (2018), Papagiannakis and Lioukas (2018), Raineri and Paillé (2016), and Tuân et al. (2014), who emphasized the effect of leadership in different types of EB in the workplace. Furthermore, the results indicated that employees who received environmental training reported higher levels of EB than others. It means that employees who received environmental training reported higher levels of EB than others. This result agrees with Cabral and Dhar (2019), Pham et al. (2019), Pinzone et al. (2019), Singh et al. (2019), Unnikrishnan and Hegde (2007). Such a consistency confirmed a positive effect of green training on the behaviors of employees toward protecting the environment through workplaces.

The outcomes found a difference between the groups of employees who have religious values. The outcomes also indicated that the difference is for employees who have religious values. This finding generally agrees with many studies conducted in Islamic countries, which emphasized the impact of religious values on the behavior of individuals in supporting the environment (Ali et al., 2015; Ibrahim, 2018; Rice, 2006).

This study revealed that leadership support encourages employees to practice EB. Therefore, this study recommends that all leaders in government agencies provide the necessary support for employees. Leaders must also act as role models for employees to display environmentally friendly behaviors in the workplace. The study indicated that training has a 
role in the EB practice of employees. Thus, the study recommends expanding environmental training programs, including all employees and managers in government agencies, because training provides environmental knowledge and awareness. The recruitment process is examined to attract employees and leaders with reasonable beliefs, attitudes, and initiatives toward environmental issues.

According to the findings, it has been found that environmental behavior practice is generally high in government agencies in Saudi Arabia. Therefore, the current study recommends raising EB through the following. First, employees must be educated on the importance of undertaking voluntary ac- tions and initiatives for environmental protection through educational programs and various incentives. Second, employees must be informed regularly by creating an effective communication system that provides accurate and immediate information on all environmental initiatives evaluated by government agencies and other organizations in society to promote awareness and effective participation. Third, opportunities must be provided to employees to express their thoughts and opinions on environmental issues. Finally, these issues must be solved by producing a democratic approach to management, which enables the expression of their views in complete freedom.

\title{
CONCLUSION
}

The study attempts to examine the level of EB practice in Saudi government agencies. This paper used six dimensions, namely gender, marital status, educational level, leadership support, environmental training, and religious values, to evaluate EB's degree in Saudi Arabia government agencies. The results found that divorced employees, employees with high school education, employees who receive leadership support and environmental training, and those who embrace Islamic religious values are considerably involved in the practice of EB in government agencies. The present study also revealed a significant difference between married, unmarried, divorced, high school, graduate, postgraduate, those who receive and do not receive leadership support in Saudi government agencies. In addition, employees who received environmental training reported higher levels of EB than others. Finally, the results also indicated a difference between employees who have religious values.

The findings have considerable implications for researchers, regulators, policymakers, managers, governors, and academicians. This study seeks to fill the existing gap in the environmental behavior literature and adds to the study of the degree of environmental behavior in government agencies. There is a lack of investigations on environmental behavior in government agencies in Saudi Arabia. However, this paper is one of the few studies on environmental behavior (EB) in governmental agencies. This study also establishes a basis for researchers to conduct additional investigations into the relationship of EB with other variables in governmental organizations. Moreover, the current study can guide researchers from other contexts in the world to conduct comparative studies between their countries and Saudi Arabia in environmental management in public organizations.

\section{DISCLOSURE STATEMENT}

The author declares that he does not have any competing financial, professional, or personal interests from other parties.

\section{AUTHOR CONTRIBUTIONS}

\author{
Conceptualization: Abdulmalek Taher Alhajj. \\ Data curation: Abdulmalek Taher Alhajj. \\ Formal analysis: Abdulmalek Taher Alhajj.
}


Funding acquisition: Abdulmalek Taher Alhajj.

Investigation: Abdulmalek Taher Alhajj.

Methodology: Abdulmalek Taher Alhajj.

Project administration: Abdulmalek Taher Alhajj.

Resources: Abdulmalek Taher Alhajj.

Software: Abdulmalek Taher Alhajj.

Supervision: Abdulmalek Taher Alhajj.

Writing - original draft: Abdulmalek Taher Alhajj.

Writing - review \& editing: Abdulmalek Taher Alhajj.

\section{ACKNOWLEDGMENT}

The author thanks the Deanship of Scientific Research at King Saud University for supporting this study.

\section{REFERENCES}

1. Abdulghaffar, N. (2017). Green Workplace Behaviour in Saudi Arabia: The Case of EnviroCo. Journal of Management and Sustainability, 7(1), 19-28. https:// doi.org/10.5539/jms.v7n1p19

2. Abedi-Sarvestani, A., \& Shahvali, M. (2008). Environmental Ethics : Toward an Islamic Perspective Environmental. American-Eurasian Journal of Agricultural and Environmental Sciences, 3(4), 606617. Retrieved from http://www. idosi.org/aejaes/jaes3(4)/15.pdf

3. Ahmad, S., \& Nisar, T. (rev.ed.). (2015). Green Human Resource Management: Policies and Practices. Cogent Business and Management, 2(1), 1-13. https://doi.org/10.1080/2 3311975.2015.1030817

4. Ajzen, I. (1985). From intentions to actions: A theory of planned behavior. In J. Kuhl, \& J. Beckmann (Eds.), Action control (pp. 11-39). Springer, Berlin, Heidelberg. https:// doi.org/10.1007/978-3-642-697463_2

5. Ajzen, I. (2015). The Theory of Planned Behaviour Is Alive and Well, and Not Ready to Retire: A Commentary on Sniehotta, Presseau, and Araújo-Soares. Health Psychology Review, 9(2), 131-137. https://doi.org/10.1080/17437199.2 014.883474

6. Akhtar, M. R. (1996). Towards an Islamic Approach for Environmental Balance. Islamic Economic Studies, 3(2), 57-76.
Retrieved from https://papers.ssrn. com/sol3/papers.cfm?abstract_ id $=3165366$

7. Albahairy, H. (2018). The Effect of Applying the Concept of Green Human Resources Management (GHRM) on Activating Human Resource Management Practices in the Egyptian Business Environment. Journal of Business and Environmental Studies, 9(2), 102-140.

8. Ali, A., Sherwani, M., \& Ali, A. (2015). Environmental Concern and Pro-Environment Behavior in a Pakistani Sample within an Individual Religiosity Framework. Global Journal of Advanced Research, 2(5), 865-876. Retrieved from http:// www.gjar.org/publishpaper/vol2issue5/d95r52.pdf

9. Amenumey, F. (2015). Variables That Impact Environmental Sustainability Behaviors of Employees in the Textile Manufacturing Industry in Ghana. University of Minnesota. Retrieved from https://conservancy.umn.edu/ bitstream/handle/11299/174881/ Amenumey_umn_0130E_15970. pdf

10. Anderson, A. J., Ahmad, A. S., King, E. B., Lindsey, A. P., Feyre, R. P., Ragone, S., \& Kim, S. (2015). The Effectiveness of Three Strategies to Reduce the Influence of Bias in Evaluations of Female Leaders. Journal of Applied Social Psychology, 45(9), 522-539. https://doi. org/10.1111/jasp.12317
11. Aziz, F., Mahadi, N., \& Mohammad, J. (2018). Employee Pro-Environmental Behaviour: A Systematic Review and Suggestions for Future Research. The Journal of Social Sciences Research, 2, 272280. https://doi.org/10.32861/jssr. spi2.272.280

12. Beck, L., \& Ajzen, I. (1991). Predicting Dishonest Actions Using the Theory of Planned Behavior. Journal of Research in Personality, 25(3), 285-301. https://doi. org/10.1016/0092-6566(91)90021-H

13. Bissing-Olson, M. J., Iyer, A., Fielding, K. S., \& Zacher, H. (2013). Relationships between Daily Affect and Pro-Environmental Behavior at Work: The Moderating Role of proEnvironmental Attitude. Journal of Organizational Behavior, 34(2), 156-175. https://doi.org/10.1002/ job. 1788

14. Blok, V., Wesselink, R., Studynka, O., \& Kemp, R. (2015). Encouraging Sustainability in the Workplace: A Survey on the pro-Environmental Behavior of University Employee. Journal of Cleaner Production, 106, 55-67. https://doi.org/10.1016/j. jclepro.2014.07.063

15. Boiral, O. (2009). Greening the Corporation Through Organizational Citizenship Behaviors. Journal of Business Ethics, 87, 221-236. https://doi.org/10.1007/ s10551-008-9881-2

16. Boiral, O., Cayer, M., \& Baron, C. M. (2009). The Action Logics 
of Environmental Leadership: A Developmental Perspective. Journal of Business Ethics, 85(4), 479-499. https://doi.org/10.1007/s10551-0089784-2

17. Cabral, C., \& Dhar, R. L. (2019). Green Competencies: Construct Development and Measurement Validation. Journal of Cleaner Production, 235, 887-900. https://doi. org/10.1016/j.jclepro.2019.07.014

18. Chen, X., Peterson, M. N., Hull, V., Lu, C., Lee, G. D., Hong, D., \& Liu, J. (2011). Effects of Attitudinal and Sociodemographic Factors on ProEnvironmental Behaviour in Urban China. Environmental Conservation, 38(1), 45-52. https://doi. org/10.1017/S037689291000086X

19. Cherian, J. P., \& Jolly, J. (2012). A Study of Green HR Practices and Its Effective Implementation in the Organization: A Review. International Journal of Business and Management, 7(21), 25-33. https:// doi.org/10.5539/ijbm.v7n21p25

20. Cheung, S. F., Chan, D. K.-S., \& Wong, Z. S.-Y. (1999). Reexamining the Theory of Planned Behavior in Understanding Wastepaper Recycling. Environment and Behavior, 31(5), 587-612. https://doi. org/10.1177/00139169921972254

21. Chithra, M., \& Jyothi, P. (2017). Eco-Civic Engagement - A Dimension of OCBE. International Journal of Human Resource Development and Management, 7(1), 1-12. Retrieved from https://www ripublication.com/ijhrdm17/ijhrdmv7n1_01.pdf

22. Digby, C. L. B. (2013). The Influences of Socio-Demographic Factors, and Non-Formal and Informal Learning Participation on Adult Environmental Behaviors. International Electronic Journal of Environmental Education, 3(1), 3755. Retrieved from https://files.eric. ed.gov/fulltext/EJ1104862.pdf

23. Fielding, K. S., McDonald, R., \& Louis, W. R. (2008). Theory of Planned Behaviour, Identity and Intentions to Engage in Environmental Activism. Journal of Environmental Psychology, 28(4), 318-326. https://doi.org/10.1016/j. jenvp.2008.03.003
24. Francoeur, V., Paillé, P., Yuriev, A., \& Boiral, O. (2021). The Measurement of Green Workplace Behaviors: A Systematic Review. Organization \& Environment, 34(1), 18-42. https:// doi.org/10.1177/1086026619837125

25. Gatfield, T., \& Chen, C. H. (2006). Measuring Student Choice Criteria Using the Theory of Planned Behaviour: The Case of Taiwan, Australia, UK, and USA. Journal of Marketing for Higher Education, 16(1), 77-95. https://doi. org/10.1300/J050v16n01_04

26. General Authority for Statistics. (2019). Civil Service Employees in the Kingdom of Saudi Arabia. (In Arabic). Retrieved from https:// www.stats.gov.sa/ar/1017

27. Graves, L. M., Sarkis, J., \& Zhu, Q. (2013). How Transformational Leadership and Employee Motivation Combine to Predict Employee Proenvironmental Behaviors in China. Journal of Environmental Psychology, 35, 81-91. https://doi.org/10.1016/j. jenvp.2013.05.002

28. Haney, A. B., Pope, J., \& Arden, Z. (2020). Making It Personal: Developing Sustainability Leaders in Business. Organization \& Environment, 33(2), 155-174. https:// doi.org/10.1177/1086026618806201

29. Harland, P., Staats, H., \& Wilke, H. A. M. (2007). Situational and Personality Factors as Direct or Personal Norm Mediated Predictors of Pro-Environmental Behavior: Questions Derived from Norm-Activation Theory. Basic and Applied Social Psychology, 29(4), 323-334. https://doi. org/10.1080/01973530701665058

30. Helfaya, A., Kotb, A., \& Hanafi, R. (2018). Qur'anic Ethics for Environmental Responsibility: Implications for Business Practice. Journal of Business Ethics, 150(4), 1105-1128. https://doi.org/10.1007/ s10551-016-3195-6

31. Hines, J. M., Hungerford, H. R., \& Tomera, A. N. (1987). Analysis and Synthesis of Research on Responsible Environmental Behavior: A Meta-Analysis. Journal of Environmental Education, 18(2), 1-8. https://doi.org/10.1080/0095896 4.1987.9943482
32. Hlaing, K. S. (2016). The Effects of Environmental Knowledge, Environmental Attitude and Socio Demographic Factors on Proenvironmental Behavior in Mandalay. Yadanabon University. Retrieved from https://meral.edu. $\mathrm{mm} /$ records/427?community=ydbu

33. Ho, S. S., Liao, Y., \& Rosenthal, S. (2015). Applying the Theory of Planned Behavior and Media Dependency Theory: Predictors of Public Pro-Environmental Behavioral Intentions in Singapore. Environmental Communication, 9(1), 77-99. https://doi.org/10.1080/1752 4032.2014.932819

34. Ibrahim, M. (2018). Proposed Model of Antecedent and Consequences of Employee's Environmental Green: An Empirical Study in Saudi Industrial Investment Companies. Journal of Administrative Sciences, 25(3), 399-443.

35. Iqbal, Q., Hassan, S. H., Akhtar, S., \& Khan, S. (2018). Employee's Green Behavior for Environmental Sustainability: A Case of Banking Sector in Pakistan. World Journal of Science, Technology and Sustainable Development, 15(2), 118-130. https://doi.org/10.1108/ wjstsd-08-2017-0025

36. Jabbour, C. J. C., \& Santos, F. C A. (2008). The Central Role of Human Resource Management in the Search for Sustainable Organizations. International Journal of Human Resource Management, 19(12), 2133-2154. https://doi. org/10.1080/09585190802479389

37. Janmaimool, P., \& Denpaiboon, C. (2016). Evaluating Determinants of Rural Villagers' Engagement in Conservation and Waste Management Behaviors Based on Integrated Conceptual Framework of Pro-Environmental Behavior. Life Sciences, Society and Policy, 12(1). https://doi.org/10.1186/s40504-0160045-3

38. Jurin, R. R., \& Fortner, R. W. (2002). Symbolic Beliefs as Barriers to Responsible Environmental Behavior. Environmental Education Research, 8(4), 373-394. https://doi. org/10.1080/1350462022000026791 
39. Kim, Y. J., Kim, W. G., Choi, H.-M., \& Phetvaroon, K. (2019). The Effect of Green Human Resource Management on Hotel Employees' Eco-Friendly Behavior and Environmental Performance. International Journal of Hospitality Management, 76(A), 83-93. https:// doi.org/10.1016/j.ijhm.2018.04.007

40. Kollmuss, A., \& Agyeman, J. (2002). Mind the Gap: Why Do People Act Environmentally and What Are the Barriers to pro-Environmental Behavior? Environmental Education Research, 8(3), 239-260. https://doi. org/10.1080/13504620220145401

41. Lakhan, C. (2018). The Garbage Gospel: Using the Theory of Planned Behavior to Explain the Role of Religious Institutions in Affecting pro-Environmental Behavior among Ethnic Minorities. The Journal of Environmental Education, 49(1), 43-58. https://doi. org/10.1080/00958964.2017.1337 701

42. Leeuw, A., Valois, P., Ajzen, I., \& Schmidt, P. (2015). Using the Theory of Planned Behavior to Identify Key Beliefs Underlying ProEnvironmental Behavior in HighSchool Students: Implications for Educational Interventions. Journal of Environmental Psychology, 42, 128-138. https://doi.org/10.1016/j. jenvp.2015.03.005

43. Liang, Y., Kee, K. F., \& Henderson, L. K. (2018). Towards an Integrated Model of Strategic Environmental Communication: Advancing Theories of Reactance and Planned Behavior in a Water Conservation Context. Environmental Communication, 46(2), 135-154. https://doi.org/10.1080/00909882.2 018.1437924

44. Liu, P., Teng, M., \& Han, C. (2020). How Does Environmental Knowledge Translate into ProEnvironmental Behaviors?: The Mediating Role of Environmental Attitudes and Behavioral Intentions. Science of the Total Environment, 728, 138126. https://doi.org/10.1016/j. scitotenv.2020.138126

45. Liu, X., Zou, Y., \& Wu, J. (2018). Factors Influencing Public-Sphere pro-Environmental Behavior among Mongolian College Students:
A Test of Value-Belief-Norm Theory. Sustainability, 10(5), 1384. https:// doi.org/10.3390/su10051384

46. Mashala, Y. (2018). Green Human Resource Management and Environmental Sustainability in Tanzania: A Review and Research Agenda. International Journal of Academic Multidisciplinary, 2(12), 60-68.

47. Masri, H. A., \& Jaaron, A. A. M. (2017). Assessing Green Human Resources Management Practices in Palestinian Manufacturing Context: An Empirical Study. Journal of Cleaner Production, 143, 474-489. https://doi.org/10.1016/j. jclepro.2016.12.087

48. Mat, N. H. N., Mohamed, M., Fawehinmi, O., Yusliza, M.-Y., \& Saputra, J. (2020). Investigating the Antecedents of Students' Pro- Environmental Behaviour in the Malaysian Public University. Journal of Talent Development and Excellence, 12(3s), 1953-1969. Retrieved from http://iratde.com/ index.php/jtde/article/view/574

49. Mishra, P. (2017). Green Human Resource Management: A Framework for Sustainable Organizational Development in an Emerging Economy. International Journal of Organizational Analysis, 25(5), 762-788. https://doi. org/10.1108/IJOA-11-2016-1079

50. Morren, M., \& Grinstein, A. (2016). Explaining Environmental Behavior across Borders: A Meta-Analysis. Journal of Environmental Psychology, 47, 91-106. https://doi.org/10.1016/j. jenvp.2016.05.003

51. Norton, T. A., Parker, S. L., Zacher, H., \& Ashkanasy, N. M. (2015). Employee Green Behavior: A Theoretical Framework, Multilevel Review, and Future Research Agenda. Organization \& Environment, 28(1), 103-125. https:// doi.org/10.1177/1086026615575773

52. Octav-Ionut, M. (2015). Applying the Theory of Planned Behavior in Predicting Pro- Environmental Behaviour: The Case of Energy Conservation. Acta Universitatis Danubius, 11(4), 15-32.

53. Ones, D. S., \& Dilchert, S. (2012). Environmental Sustainability at
Work: A Call to Action. Industrial and Organizational Psychology, 5(4), 444-466. https://doi.org/10.1111/ j.1754-9434.2012.01478.x

54. Paillé, P., \& Boiral, O. (2013). Pro-Environmental Behavior at Work: Construct Validity and Determinants. Journal of Environmental Psychology, 36, 118-128. https://doi.org/10.1016/j. jenvp.2013.07.014

55. Pamuk, S., \& Kahriman-Pamuk, D. (2019). Preservice Teachers' Intention to Recycle and Recycling Behavior: The Role of Recycling Opportunities. International Electronic Journal of Environmental Education, 9(1), 33-45. Retrieved from https://eric ed.gov/?id=EJ1201374

56. Papagiannakis, G., \& Lioukas, $\mathrm{S}$. (2018). Corporate Environmental Management: Individual-Level Drivers and the Moderating Role of Charismatic Leadership. European Management Review, 15(4), 475-489. https://doi.org/10.1111/emre.12134

57. Patel, J., Modi, A., \& Paul, J. (2017) Pro-Environmental Behavior and Socio-Demographic Factors in an Emerging Market. Asian Journal of Business Ethics, 6(2), 189-214. https://doi.org/10.1007/s13520-0160071-5

58. Pham, N. T., Tučková, Z., \& Phan, Q. P. T. (2019). Greening Human Resource Management and Employee Commitment Towards the Environment: An Interaction Model. Journal of Business Economics and Management, 20(3), 446-465. https://doi.org/10.3846/ jbem.2019.9659

59. Pinzone, M., Guerci, M., Lettieri, E., \& Huisingh, D. (2019). Effects of 'Green' Training on proEnvironmental Behaviors and Job Satisfaction: Evidence from the Italian Healthcare Sector. Journal of Cleaner Production, 226, 221232. https://doi.org/10.1016/j. jclepro.2019.04.048

60. Raineri, N., \& Paillé, P. (2016). Linking Corporate Policy and Supervisory Support with Environmental Citizenship Behaviors: The Role of Employee Environmental Beliefs and Commitment. Journal of Business 
Ethics, 137(1), 129-148. https://doi. org/10.1007/s10551-015-2548-x

61. Ramus, C. A., \& Killmer, A. B. C. (2007). Corporate Greening through Prosocial Extrarole Behaviours - A Conceptual Framework for Employee Motivation. Business Strategy and the Environment, 16(8), 554-570. https://doi.org/10.1002/bse.504

62. Ramus, C. A., \& Steger, U. (2000). The Roles of Supervisory Support Behaviors and Environmental Policy in Employee. Academy of Management Journal, 43(4). https:// doi.org/10.5465/1556357

63. Razzaq, A., Ansari, N. Y., Razzaq, Z., \& Awan, H. M. (2018). The Impact of Fashion Involvement and Pro-Environmental Attitude on Sustainable Clothing Consumption: The Moderating Role of Islamic Religiosity. SAGE Open, 8(2). https://doi. org/10.1177/2158244018774611

64. Ren, S., Tang, G., \& Jackson, S. E. (2018). Green Human Resource Management Research in Emergence: A Review and Future Directions. Asia Pacific Journal of Management, 35(3), 769-803. https://doi.org/10.1007/s10490-0179532-1

65. Renwick, D. W. S., Redman, T., \& Maguire, S. (2013). Green Human Resource Management: A Review and Research Agenda. International Journal of Management Reviews, 15(1), 1-14. https://doi.org/10.1111/ j.1468-2370.2011.00328.x

66. Rice, G. (2006). Pro-Environmental Behavior in Egypt: Is There a Role for Islamic Environmental Ethics? Journal of Business Ethics, 65(4), 373-390. https://doi.org/10.1007/ s10551-006-0010-9

67. Robertson, J. L., \& Barling, J. (2013). Greening Organizations through Leaders' Influence on Employees' pro-Environmental Behaviors. Journal of Organizational Behavior, 34(2), 176-194. https://doi. org/10.1002/job.1820

68. Russell, R. F. (2001). The Role of Values in Leadership. Leadership $\&$ Organization Development Journal, 22(2), 76-84. https:/doi. org/10.1108/01437730110382631
69. Setyawan, A., Noermijati, N., Sunaryo, S., \& Aisjah, S. (2018). Green Product Buying Intentions among Young Consumers: Extending the Application of Theory of Planned Behavior. Problems and Perspectives in Management, 16(2), 145-154. http://dx.doi.org/10.21511/ ppm.16(2).2018.13

70. Singh, S. K., Chen, J., Giudice, M. D., \& El-Kassar, A.-N. (2019). Environmental Ethics, Environmental Performance, and Competitive Advantage: Role of Environmental Training. Technological Forecasting and Social Change, 146, 203-211. https://doi. org/10.1016/j.techfore.2019.05.032

71. Stern, P. C. (2000). Toward a Coherent Theory of Environmentally Significant Behavior. Journal of Social Issues, 56(3), 407-424. https://doi. org/10.1111/0022-4537.00175

72. Strydom, W. F. (2018). Applying the Theory of Planned Behavior to Recycling Behavior in South Africa. Recycling, 3(3), 43. https://doi. org/10.3390/recycling3030043

73. Tuân, N. P., Takahashi, Y., \& Mai, N. T. T. (2014). The roles of supervisory support behaviors and environmental policy in employee "eco-initiatives" at manufacturing companies in Vietnam. Journal of Economic Development, 221, 105126. Retrieved from http://jabes. ueh.edu.vn/Content/ArticleFiles/ oldbv_en/2014/Thang\%207/6nhamphongtuan_sua.pdf

74. Unnikrishnan, S., \& Hegde, D. S. (2007). Environmental Training and Cleaner Production in Indian Industry - A Micro-Level Study. Resources, Conservation and Recycling, 50(4), 427-441. https://doi. org/10.1016/j.resconrec.2006.07.003

75. Vicente-Molina, M. A., FernándezSainz, A., \& Izagirre-Olaizola, J. (2018). Does Gender Make a Difference in Pro-Environmental Behavior? The Case of the Basque Country University Students. Journal of Cleaner Production, 176, 89-98. https://doi.org/10.1016/j. jclepro.2017.12.079

76. Warrick, B. (2016). Examining Employee Motivation, Environmental
Systems, and Corporate Social Responsibility in Proenvironmental Behavior. Walden University. Retrieved from https://scholarworks. waldenu.edu/cgi/viewcontent.cgi?ar ticle $=4009 \&$ context $=$ dissertations $\&$ httpsredir $=1 \&$ referer $=$

77. Wesselink, R., Blok, V., \& Ringersma, J. (2017). Pro-Environmental Behaviour in the Workplace and the Role of Managers and Organisation. Journal of Cleaner Production, 168, 1679-1687. https://doi.org/10.1016/j. jclepro.2017.08.214

78. Yadav, R., \& Pathak, G. S. (2017). Determinants of Consumers' Green Purchase Behavior in a Developing Nation: Applying and Extending the Theory of Planned Behavior. Ecological Economics, 134, 114-122. https://doi.org/10.1016/j.ecolecon.2016.12.019

79. Yuriev, A., Dahmen, M., Paillé, P., Boiral, O., \& Guillaumie, L. (2020). Pro-Environmental Behaviors through the Lens of the Theory of Planned Behavior: A Scoping Review. Resources, Conservation \& Recycling, 155, 104660. https:// doi.org/10.1016/j.resconrec.2019.104660

80. Zelezny, L. C., Chua, P.-P., \& Aldrich, C. (2000). New Ways of Thinking about Environmentalism: Elaborating on Gender Differences in Environmentalism. Journal of Social Issues, 56(3), 443-457. https:// doi.org/10.1111/0022-4537.00177

81. Zhang, L., Fan, Y., Zhang, W., \& Zhang, S. (2019). Extending the Theory of Planned Behavior to Explain the Effects of Cognitive Factors across Different Kinds of Green Products. Sustainability, 11(15), 4222. https://doi. org/10.3390/su11154222 


\section{APPENDIX A. Questionnaire}

\section{Section A: General information}

Please tick the appropriate answer:

- Gender: () Man - () Woman;

- Marital status: () Married - () Unmarried - () Divorced;

- Educational level: () High school - () Graduate - () Postgraduate;

- Leadership support: () Receives support - () Does not receive support;

- Training: () Yes - () No;

- Religious value: () Effective - () Not effective - () Null.

\section{Section B: Environmental behavior}

Please tick the appropriate answer that describes your opinion.

Table A1. Questionnaire table

\begin{tabular}{|c|c|c|c|c|c|c|}
\hline Dimensions & Items & $\begin{array}{l}\text { Strongly } \\
\text { agree }\end{array}$ & Agree & Neutral & Disagree & $\begin{array}{l}\text { Strongly } \\
\text { disagree }\end{array}$ \\
\hline \multirow{3}{*}{$\begin{array}{l}\text { Eco- } \\
\text { initiatives }\end{array}$} & $\begin{array}{l}\text { In my work, I weigh the consequences of my actions before } \\
\text { doing something that could affect the environment }\end{array}$ & & & & & \\
\hline & $\begin{array}{l}\text { I voluntarily carry out environmental actions and initiatives } \\
\text { in my daily work activities }\end{array}$ & & & & & \\
\hline & $\begin{array}{l}\text { I make suggestions to my colleagues about ways to protect } \\
\text { the environment more effectively, even when it is not my } \\
\text { direct responsibility }\end{array}$ & & & & & \\
\hline \multirow{4}{*}{$\begin{array}{l}\text { Eco-civic } \\
\text { engagement }\end{array}$} & $\begin{array}{l}\text { I actively participate in environmental events organized in } \\
\text { and/or by my company }\end{array}$ & & & & & \\
\hline & $\begin{array}{l}\text { I stay informed about my company's environmental } \\
\text { initiatives }\end{array}$ & & & & & \\
\hline & $\begin{array}{l}\text { I undertake environmental actions that contribute positively } \\
\text { to the image of my organization }\end{array}$ & & & & & \\
\hline & $\begin{array}{l}\text { I volunteer for projects, endeavors, or events that address } \\
\text { environmental issues in my organization }\end{array}$ & & & & & \\
\hline \multirow{3}{*}{ Eco-helping } & $\begin{array}{l}\text { I spontaneously give my time to help my colleagues take the } \\
\text { environment into account in everything they do at work }\end{array}$ & & & & & \\
\hline & $\begin{array}{l}\text { I encourage my colleagues to adopt more environmentally } \\
\text { conscious behaviors }\end{array}$ & & & & & \\
\hline & $\begin{array}{l}\text { I encourage my colleagues to express their ideas and } \\
\text { opinions on environmental issues }\end{array}$ & & & & & \\
\hline
\end{tabular}

